International Journal of Instruction e-ISSN: 1308-1470 • www.e-iji.net

Article submission code: 20191205025201

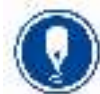

January $2021 \bullet$ Vol.14, No.1

p-ISSN: 1694-609X

pp. $365-378$

Received: 05/12/2019

Revision: 25/06/2020
Accepted: 17/07/2020

OnlineFirst:18/10/2020

\title{
The Correlation between Religiosity and Multiple Intelligences: A Meta- Analysis
}

\section{Kemanya Karbono}

Doctoral Student Yogyakarta State University, Sriwijaya State Buddhist College, Indonesia, kemanya.2017@student.uny.ac.id

\section{Heri Retnawati}

Dr. Graduate School, Yogyakarta State University, Indonesia,heri_retnawati@uny.ac.id

The disparity in the results of the study of the correlation between religiosity and multiple intelligences is an important use of meta-analysis, so that it can be used as credible literature by looking at multiple intelligences not only as analytical intelligence. This study involved 3242 samples that varied, age, culture, and academics, from 18 publications and non-publication articles, from 1998 to 2016. The results of the study showed that there is a significant correlation between religiosity and multiple intelligences, which obtained an $r$ value of 0.41 with a confidence interval range of 0.164 to 0.518 , so this correlation is in the medium category.

Keywords: religiosity, multiple intelligences, meta-analysis, intelligence, correlation

\section{INTRODUCTION}

The studies on the correlation between religiosity and multiple intelligences, especially intelligence, have been carried out by researchers with subject variants from children to adults. The benefits of religiosity are often seen in the context of life after death. However, religious beliefs and religious communities that are part of religiosity have been discovered by researchers, apparently affecting individuals in various aspects of real life, such as emotional control (Chisiu, 2017), academic abilities (Byfield, 2008; Zubairu \& Sakariyau, 2016), life satisfaction (ten Kate et al, 2017). The effect of religiosity on academic ability is more significant in urban societies (Jeynes, 2003). In line with, Li \& Murphy (2017) examined with a sample of students at the university concluded that there is a positive correlation between academic performance and religiosity, especially in Christian students. Although there have been many studies regarding the correlation between religiosity and intelligence, there has not been a systematic study of the correlation between religiosity and multiple intelligences.

The psychologists do a lot of study on the role of religiosity in one's interpretation and response to the reality of life, in terms of psychological aspects, especially related to emotional intelligence and mental health. Jung (2005) and Allport (1950) state that

Citation: Karbono, K., \& Retnawati, H. (2021). The Correlation between Religiosity and Multiple Intelligences: A Meta-Analysis. International Journal of Instruction, 14(1), 365-378. https://doi.org/10.29333/iji.2021.14121a 
religiosity as a source of meaning and stability in uncertainty in the world is positive, religiosity influences various aspects of life, both physically and psychologically and is recognized as an important feture of human society (Dennet, 2006). The statement is proven by Bergin (1991) in a study that concluded that there is a positive correlation between religiosity and mental health, which reached an $r$ value of 0.09 . Even Bergin also suggested that in medical education it is important to include value education and religious issues, so that religious clients can be served well. This is according to the results of Abolghasem-Gorji et al (2017) research thet religiosity can improve the quality of life of heart failure patients.

In line with this, Elena (2014) states that religiosity or spiritual intelligence also has a correlation with emotional intelligence, this concludes that one's emotional intelligence varies significantly, depending on the level of religiosity and spiritual experience. The correlation shows that spiritual intelligence has a positive impact on the educational process. It is based on the fact that emotional intelligence also influences other intelligence such as the results of research by Ebrahimi, et al (2018) which states that emotional intelligence significantly influences writing skills.

The religiosity, besides influencing health, also affects other aspects of life. Regnerus (2000) states that individuals who are diligent in participating in church activities can increase educational expectations and achievements. It found that more religious students scored higher in standardized tests in mathematics and reading, outside of ecological factors, such as social classes. Compensation factors in life for black students in the United States and Britain, such as parents who support educational values and strong religious beliefs apparently support academic success (Byfield, 2007).

Contradicting to the results of Regnerus's study, many studies have also shown that high levels of religiosity have been associated with lower levels of intelligence. For example, the study of Gary, Stuart, \& Timothy (2011) which takes samples of adults in the United States, where the variable religiosity is measured by multi-scale and controls the influence of personality openness on aspects of religious beliefs and practices. They concluded that lower intelligence is very concerned with higher levels of fundamentalism, and higher levels of openness are often assumed to lead to lower religiosity. This is in accordance with the results of Dutton's study (2014) which states that individuals and societies that are more intelligent tend to be less religious than those who lack intelligence. It is further said that these findings are in line with developmental trends: Individuals tend to be religious in the kindergarten, and become less religious when they reach the highest cognitive abilities, and then alternately become more religious when their cognitive abilities decline in old age.

There is a disparity in the results of study regarding the correlation between religiosity and multiple intelligences, so it is deemed necessary to conduct a study systematically, regarding the correlation between religiosity and multiple intelligences. This study aims to conduct a systematic study of the correlation between religiosity and multiple intelligences that do not only see multiple intelligences as analytic intelligence. In addition, this study looks at the correlation between religiosity and multiple intelligences in a more comprehensive manner, in terms of the sample aspects that are varied, both age, culture, and academic, so that it will produce more accurate conclusions. 


\section{Study of Religiosity and Multiple Intelligences}

Religiosity comes from the word 'religio/religare' which means binding. This means that in religion there are rules and obligations that bind individuals or groups of individuals in interactions, both vertically and horizontally. In Roget's Thesaurus (Morehead, 2001), the word 'religiosity' is found to be synonymous with terms, such as religious, orthodox, faith, belief, obedience, devotion, and holiness. These synonym words reflect the study of religiosity, what would be called a religiosity variable, rather than a term equivalent to religiosity. There is no overall agreement from the researchers regarding the concept of religiosity, so that this concept crosses several academic disciplines. However, each approached religiosity from a different point of view, and some interrelated with each other (Cardwell, 1980). A theologian will discuss religiosity from the standpoint of faith (Groome \& Corso, 1999), while religious educators can focus on orthodox and beliefs (Groome, 1998). Psychologists are more likely to aim at the variables of devotion, purity, and obedience, while sociologists will consider the concept of religiosity to include church membership, church attendance, and acceptance of beliefs, doctrinal knowledge, and exercising faith (Cardwell, 1980). Basically, these views are relevant to current research. In more recent literature, Bergan \& McConatha (2001) provides a more comprehensive definition of religiosity as a number of dimensions related to religious belief and involvement. Other dimensions that can be used as a more accurate measure of religiosity such as religious presence, personal devotion, and religious belief systems (Kristensen et al, 2001).

Religiosity can be viewed from various aspects, so there is no definite agreement regarding the definition. However, religiosity is the internalization of religious values in the individual personal adherents that appear in mind, speech, and physical actions. Stark \& Glock (1974) revealed that there are five variables of religiosity, namely: religious belief, religious practice, religious feeling, religious knowledge, and religious effects. In this study, the concept of religiosity refers more to the theory of Stark \& Glock (1974). Where the process of shaping the religious character of students can be integrated in all lessons using various learning models and not only through religious education, such as the results of the research of Hawa et al (2019), that by applying the Contextual and Spiritual Quotient learning model (CSQ) to Sociology subjects can form spirituality character.

Gottfredson (1997) defines multiple intelligences as the ability to think, plan, solve problems, think abstractly, understand complex ideas, learn quickly and learn from experience. Whereas Feurestein et al (2002) define as humanity's unique tendency to change or modify the structure of cognitive functions to adapt to changes and demands of life situations. In line with this, Anderson (2006) defines religiosity as aspects of the mind that underlie the ability of individuals to think, solve problems, reason, and have knowledge about the world. Based on this definition, intelligence is basically defined as the ability to adapt and solve problems.

Conventional thought patterns emphasize intelligence in two aspects, namely logic and language. This is supported by the thought of Ornstein (2007) who examined the right and left hemispheres. The two hemispheres of the brain have their respective functions. 
The left hemisphere controls mental activities that include mathematics, language, logic, analysis, writing, and other similar activities. While the right brain handles activities that include imagination, color, music, rhythm, daydreaming, and other similar activities. The results of the study are more likely to define multiple intelligences as analytical intelligence. In a recent study, much other intelligence is identified as multiple intelligences, including creative intelligence (Sternberg, 2005) or emotional intelligence (Mayer at al., 1999). Mayer, through his study, concluded that emotional intelligence fulfills the criteria of three classical intelligences, namely: (1) being able to operate as a set of abilities; (2) meet certain correlation criteria: the capabilities determined by intelligence must form a set of (i.e., intercorrelations), and (3) regarding with existing intelligence. The latest theory related to intelligences is presented by Gardner (2011; 2006) about multiple intelligences, which in essence distinguishes human intelligence into specific modalities rather than seeing intelligence dominated by a single general ability.

\section{METHOD}

\section{Study Selection}

The studies included in the meta-analysis are tailored to the objectives. In this case the author looks for relevant articles at http://search.ebscohost.com, Google scholar, Google search, Elsevier, and others, with keywords religiosity, spiritual intelligence, multiple intelligences, emotional intelligences, correlations between religiosity and academic achievement.

The articles included in the meta-analysis are articles concerning the correlation between religiosity and multiple intelligences, both in Indonesian and English, from 1998 to 2016. Several studies are the results of unpublished theses and theses, while published studies originate from various journals, including journal psychology, economics, social behavior, mental health, religion and culture, and evaluation and study education. Studies taken, both published and unpublished, are carried out to eliminate any publications bias. If the meta-analysis is only conducted on published study reports, there is a possibility that the results are not optimal. This is based on the assumption that researchers are reluctant to send study that is not significant and the reviewers also tend to reject study reports that are not meaningful (Nindrea, 2016).

The research design used in this study is the correlation meta-analysis, where the statistical analysis is to calculate the effect size and summary effect. If the results of a regression study to be carried out in a meta-analysis study do not report the value of $r$ but report the values of $F$ and $t$, then that value must be transformed to $r$. According to Retnawati et al (2018), the calculation is done through the following equation:

$$
\begin{aligned}
& \mathrm{F}=\mathrm{t}^{2} \\
& \mathrm{Ft}=\sqrt{F} \\
& \mathrm{Fr}=\frac{\mathrm{t}}{\sqrt{\mathrm{t}^{2}}+\mathrm{N}-2}
\end{aligned}
$$


Measurement of variables in articles that were analyzed meta using various instruments. Instruments used to measure religiosity include: scale of religiosity, Inspirit Questionnaire, Religious Orientation Scale, and Francis Scale of Attitude toward Christiani. While the instruments used to measure multiple intelligences include: Emotional Intelligence Scale, Moral Intelligence Scale, learning outcomes, Cumulative Grade Point Average, Culture Free Intelligences Test, report cards, Grade Point Average Index, and grades. In total there are 18 studies are analyzed by meta-analysis, with various measurement instruments. The following Table 1 is a table of study recapitulation analyzed.

Table 1

Overview of studies included in the meta-analysis

\begin{tabular}{|c|c|c|c|c|}
\hline Study & $\begin{array}{l}\text { Numbers } \\
\mathrm{N}\end{array}$ & $\begin{array}{l}\text { Religiosity Measuring } \\
\text { Instrument }\end{array}$ & $\begin{array}{l}\text { Instrument Measuring } \\
\text { Multiple Intelligences }\end{array}$ & Sample \\
\hline $\begin{array}{l}\text { Deify \& } \\
\text { Wahyuningsih (2005) }\end{array}$ & 26 & Scale of religiosity & $\begin{array}{l}\text { Culture Fair or Culture Free } \\
\text { Intelligence Test }\end{array}$ & University students \\
\hline Chrisnawati (2008) & 50 & Scale of Religiosity & Emotional Intelligence Scale & University students \\
\hline Zikri (2015) & 127 & Scale of religiosity & Moral Intelligence Scale & Adult \\
\hline Widiyawati (2015) & 51 & Scale of Religiosity & Emotional Intelligence Scale & Teenagers \\
\hline Wicaksono (2015) & 100 & $\begin{array}{l}\text { Religiosity } \\
\text { Questionnaire }\end{array}$ & MCQ value & University students \\
\hline $\begin{array}{l}\text { Schubmehl, et al } \\
\text { (2009) }\end{array}$ & 247 & $\begin{array}{l}\text { Inspirit } \\
\text { Questionnaires }\end{array}$ & Grade Point Average & University students \\
\hline Wahaningsih (2012) & 137 & Scale of relativity & Report card value & Secondary students \\
\hline Marliani (2016) & 115 & Scale of Religiosity & GPA & University students \\
\hline Francis (1998) & 711 & $\begin{array}{l}\text { Francis Scale of } \\
\text { Attitude toward } \\
\text { Christiani }\end{array}$ & $\begin{array}{l}\text { Standard Progressive } \\
\text { Matrices }\end{array}$ & $\begin{array}{l}\text { Teenagers of } 15-16 \\
\text { years }\end{array}$ \\
\hline Alwi (2010) & 84 & Scale of Religiosity & $\begin{array}{l}\text { Religious values, } \\
\text { Citizenship, Mathematics, } \\
\text { English, Indonesian } \\
\text { Language }\end{array}$ & $\begin{array}{l}\text { Students of 16-18 } \\
\text { years }\end{array}$ \\
\hline $\begin{array}{l}\text { Wibowo, Susanto, } \\
\text { Sagita (2015) }\end{array}$ & 76 & Scale of Religiosity & Learning Achievement & $\begin{array}{l}\text { High school } \\
\text { students }\end{array}$ \\
\hline Liu (2010) & 497 & $\begin{array}{l}\text { Religious Orientation } \\
\text { Scale }\end{array}$ & $\begin{array}{l}\text { Emotional Intelligence } \\
\text { Questionaire }\end{array}$ & University students \\
\hline Sari (2012) & 40 & Scale of Religiosity & Emotional Intelligence Scale & $\begin{array}{l}\text { Students of Aliyah } \\
\text { Madrasah }\end{array}$ \\
\hline Rasmanah (2003) & 165 & Scale of Religiosity & Emotional Intelligence Scale & MAN students \\
\hline Mustafidah (2008) & 160 & Scale of Religiosity & Odd Semester Value & $\begin{array}{l}\text { High school } \\
\text { students }\end{array}$ \\
\hline Sukmarani (2016) & 63 & Scale of Religiosity & Learning Outcomes & $\begin{array}{l}\text { Elementary School } \\
\text { Students class of } 5 \\
\end{array}$ \\
\hline $\begin{array}{l}\text { Zubairu Dan } \\
\text { Sakariyau (2016) }\end{array}$ & 302 & Religiosity Scale & $\begin{array}{l}\text { Cumulative Grade Point } \\
\text { Averages (CGPA) }\end{array}$ & University students \\
\hline $\begin{array}{l}\text { Hamjah, Rozali, } \\
\text { Rasit, \& Ismail } \\
(2010)\end{array}$ & 291 & Spiritual Practice & $\begin{array}{l}\text { Academic Achievement } \\
\text { (GPA) }\end{array}$ & University students \\
\hline
\end{tabular}




\section{Sample}

The total sample in this meta-analysis is 3242 respondents. The sample in this study is very varied from the youngest age, namely grade 5 elementary school (Sukamarani, 2016), junior high school students (Wahaningsih, 2012), students of Madrasah Aliyah (Sari, 2012), adolescents aged 15-16 years (Francis, 1998), students of senior high school 16-18 years (Alwi, 2010), students (Deify \& Wahyuningsih, 2005; Chrisnawati, 2008; Wicaksono, 2011; Schubmehl, et al, 2009; Marliani, 2012; Liu, 2010; Zubairu \& Sakariyau, 2016; Hamjah et al. , 2010), and adults (Zikri, 2015). The study is an article from study conducted in several European and Asian countries.

\section{Hypothesis}

The hypothesis proposed, in this meta-analysis, is:

$\mathrm{H} 0=$ There is no significant correlation between religiosity and multiple intelligences

$\mathrm{H} 1=$ There is a significant correlation between religiosity and multiple intelligences

\section{Data Analysis}

The meta-analysis in this study is a meta-correlation analysis. The analysis used is statistical analysis. In simple terms, data analysis is carried out in several stages, namely: First, is to do a study selection, this is about finding articles that are relevant to the objectives of the meta-analysis. Second, is to convert data that still has a value of $\mathrm{F}$ or $\mathrm{t}$ to the value of $\mathrm{r}$. Third, heterogeneity testing, this is done to determine whether the analysis uses a random effect model or fix model. If it is heterogeneous, then the analysis uses random effect models. Analysis through the forest plot is also done to clarify conclusions. Fourth is by conducting publication analysis bias. The analysis is carried out with the help of JASP software. The meta-statistical correlation analysis schema used in this article consists of several steps, namely: (1) correlation coefficient; (2) transformation $r$ to $z$; (3) heterogeneity test; (4) count of summary effects; (5) conversion of results to $r$; (6) interpretation; (7) reporting.

\section{FINDINGS}

\section{Calculates Effect Size}

To calculate the effect size, the first thing to do is to transform data that has the value $\mathrm{F}$ or $t$ to be the value of $r$. Of the 18 studies in the meta-analysis, one study presents the value of $\mathrm{t}$ (Wahaningsih study, 2012), and three studies that only present $\mathrm{F}$ values (Rasmanah, 2003; Mustafidah, 2008; and Sukmarani, 2016). In the correlation metaanalysis, after all studies have obtained the value " $\mathrm{r}$ ", the $\mathrm{r}$ value is further transformed to $z$ or $y$. The results of recapitulation of the value of $r$ from each study that has been transformed to $z$ or $y$ can be seen in table 2 . 
Table 2

Transformation of value $\mathrm{r}$ to $\mathrm{z}$ or $\mathrm{y}$ to calculate summary effect and heterogeneity test

\begin{tabular}{llll}
\hline Studi & $\mathrm{r}$ & $\mathrm{y}$ & $\mathrm{V}_{\mathrm{v}}$ \\
\hline Deify \& Wahyuningsih (2018) & 0,123 & 0,124 & 0,043 \\
\hline Chrisnawati (2008) & 0,447 & 0,481 & 0,021 \\
\hline Irsyad Zikri (2015) & 0,446 & 0,480 & 0,008 \\
\hline Seli Widiyawati (2015) & 0,877 & 1,363 & 0,021 \\
\hline Candra Widhi Wicaksono (2011) & 0,085 & 0,085 & 0,010 \\
\hline William Van Omum (2009) & 0,049 & 0,049 & 0,004 \\
\hline Musiatun Wahaningsih (2012) & 0,006 & 0,006 & 0,007 \\
\hline Roseleny Marliani (2012) & 0,032 & 0,032 & 0,009 \\
\hline Leslie J Francis (1998) & $-0,019$ & $-0,019$ & 0,001 \\
\hline Said Alwi (2010) & 0,393 & 0,415 & 0,012 \\
\hline Wibowo, Susanto, Sagita (2015) & 0,600 & 0,693 & 0,014 \\
\hline Chung-Chu Liu (2010) & 0,110 & 0,110 & 0,002 \\
\hline Fatmah Sari (2016) & 0,696 & 0,860 & 0,027 \\
\hline Manah Rasmanah (2003) & 0,519 & 0,575 & 0,006 \\
\hline Lilik Mustafidah (2008) & 0,463 & 0,501 & 0,006 \\
\hline Ratri Sukmarani (2016) & 0,900 & 1,474 & 0,017 \\
\hline Zubairu Dan Zakariyau (2016) & $-0,036$ & $-0,036$ & 0,003 \\
\hline Hamjah, et al(2010) & 0,262 & 0,268 & 0,003 \\
\hline
\end{tabular}

\section{Heterogeneity Test of Effect Size}

Heterogeneity test is conducted to prove whether the effect size of each study is different. In addition, the results of heterogeneity tests are conducted to determine the model to be used in calculating the summary effect. Heterogeneity test can be done by various methods, in this article heterogeneity test is carried out with $Q$ parameter with degree of freedom $(\mathrm{df}): 18-1=17$. The results of heterogeneity testing indicate that the value of $p$ value is: $4.531 \mathrm{E}-58$ ( $\mathrm{p}$ value $<0.05$ ), because $p$ value $<0.05$, $\mathrm{H} 0$ is rejected which means that the effect size of each study is heterogeneous. Because each effect size is heterogeneous, the summary effect count uses a random effect model.

\section{Summary Effect with Random Effect Model}

To calculate the summary effect with a random effect model, the weight effect average $\left(\mathrm{M}^{*}\right)$ must be determined. The results of the manual calculation of the average effect weight $\left(\mathrm{M}^{*}\right)$ are $=0.400$. While the value of the confidence interval for $\mathrm{M}^{*}$ is as follows: lower limit value $\left(\mathrm{LLM}^{*}\right)=0.241$ while the upper limit value $\left(\mathrm{ULM}^{*}\right)=0.559$. So the value of the confidence interval for $\mathrm{M}^{*}$ is ranges from 0.241 to 0.559 .

The interval limit value must be converted to $r^{*}$, the conversion result is: lower limit value $\left(\mathrm{LLr}^{*}\right)=0.164$ while the upper limit value $\left(\mathrm{ULr}^{*}\right)=0.518$. So the value of the confidence interval for $\mathrm{r}^{*}$ is ranges from 0.164 to 0.518 . While the results of the $\mathrm{r}$ value based on the manual count are 0.380 . The $r$ value, both for each study and overall, can also be seen from the output of the Flores plot. To find out whether the hypothesis is accepted or not, you can see the value of $p$ value in the output coefficient. Next is the plot of the summary effect and output coefficient count: 


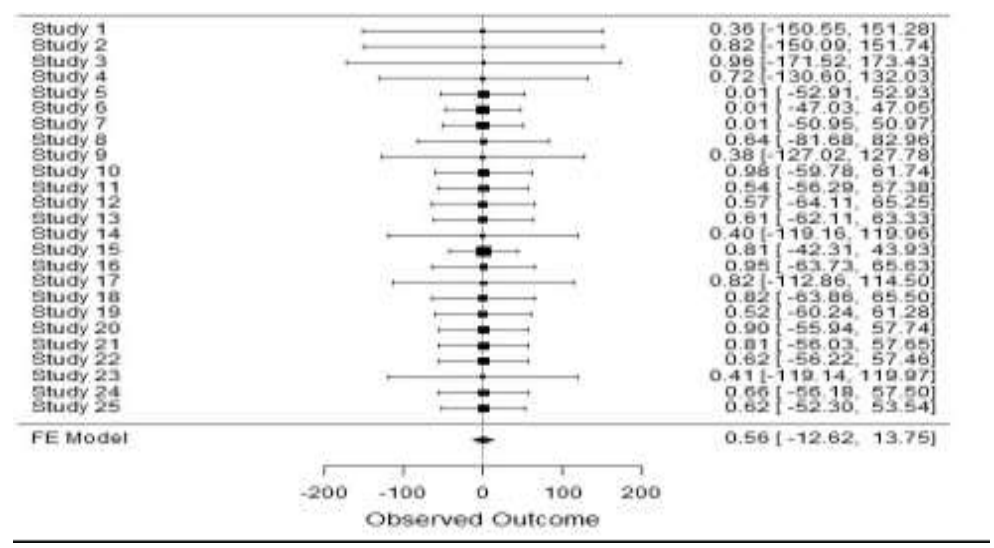

Figure 1

The value of $\mathrm{r}$ in the flores plot of counted summary effect

Based on the Flores plot above, it appears that the $r$ value for Study 1 is 0.12 with a confidence interval between -0.29 to 0.53 . There are two values that are negative, that is in Study 9 and Study 17. The biggest value of $R$ is in Study 16, which is equal to 1.47, while the lowest value of $R$ is in Study 17 which is -0.04 . The overall $r$ value of the correlation between religiosity and multiple intelligences based on the meta-analysis of 18 studies is 0.41 .

\begin{tabular}{|c|c|c|c|c|}
\hline \multicolumn{5}{|c|}{ Couffoenth } \\
\hline & Estomate & Standard Enot & $z$ & 5 \\
\hline intept & 0.4050 & 0.1050 & $386 \pi$ & $=0 \mathrm{OH}$ \\
\hline
\end{tabular}

Figure 2

The coefficients output to see $\mathrm{p}$ value

Based on the output coefficient above, it appears that the $\mathrm{p}$ value is $<0.01$. These things are also in accordance with the manual count which results in a p value of 8.09653E-07 ( $\mathrm{p}$ value $<0.01$ ). Because $\mathrm{p}$ value $<0.01$, it can be concluded that there is a significant correlation between religiosity and multiple intelligences. The $r$ value based on the above output is $0.406(0.41)$ with a confidence interval of 0.20 to 0.61 . This shows that the correlation between religiosity and multiple intelligences is in the medium category.

\section{Publication Analysis is Biased}

The publication analysis is biased on the basis of showing that the meta-analysis carried out is truly objective, in the sense that the articles that are the material of the metaanalysis are correct and show results that are in accordance with the reality in the field. To detect bias, many methods can be used. The method used to detect bias in this article 
uses Funnel plots, Rank correlation, and is reinforced with Flores plot images. Next is the funnel output plot:

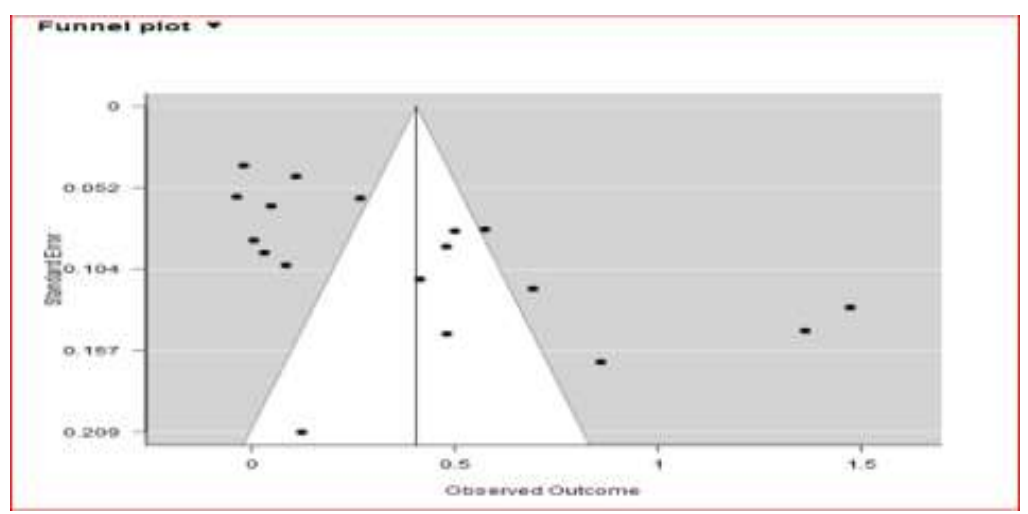

Figure 3

The Funnel Plot to see Publications Bias

Based on the funnel image plot above, it appears that 18 studies that are the subject of the meta-analysis are distributed symmetrically. This means that there is no potential for publication bias. Eighteen studies that are sample studies based on the funnel image plot above, the average is a study with a large enough sample. This can be seen in the distribution position of the study point, which is mostly located at the top.

The ideal article used in the meta-analysis is articles that are in accordance with the criteria determined by the researcher at the beginning, when going to do a meta-analysis, so it does not produce an excessive true effect size. To reduce the effects of publication bias in this article, researchers used study articles, both published and unpublished.

\section{DISCUSSION}

The results of the meta-analysis conducted show that there is a significant positive relationship between religiosity and multiple intelligences. The $r$ value of 0.41 indicates that the correlation is in a fairly strong position. The size of the relationship varies according to the type of sample (age or level of education), the nature of the measure of religiosity and multiple intelligences, and the country in which the study is conducted (Europe / west or Asia / east).

However, there are two studies, namely study 9 and study 17, which have a negative correlation. This means that according to the two studies, if a person's level of religiosity is high then this tends to be weak in the multiple intelligences, and vice versa if the level of religiosity is low then this tends to have a high level of multiple intelligences. Study 9 is a study conducted by Francis (1998) in 711 Secondary School students in England. This is in accordance with what is theorized by Dutton (2014) that in individuals (especially in the United States and Britain) who have a high level of religiosity tend to have low multiple intelligences. This is related to the view of religious 
people who tend to prioritize intuitively rather than logic. But this also states that this conclusion does not apply to samples in Japan or China (Asia).

The highest correlation lies in Study 16 with an $\mathrm{r}$ value of 1.47 . Study 16 is a study conducted by Ratri Sukmarani (2016) with a sample of 5th grade elementary school students in Malang Regency (unpublished thesis). Again the results support what Dutton (2014) said that the findings regarding the correlation between religiosity and multiple intelligences are in line with developmental trends: Individuals tend to be religious in the kindergarten, become less religious when they reach the highest cognitive abilities, and then alternately become more religious when their cognitive abilities decline in old age.

The studies carried out in Asian countries regarding the correlation of religiosity with intelligences showed that there is a positive correlation. This is assumed because the measuring instruments of religiosity are more likely to measure variables, such as the frequency of attendance in places of worship, the frequency of studying and reading scriptures, and the obedience of carrying out religious rituals. In theory, the variable religiosity, as it is more in line with the concept of extrinsic religious orientation, which is religious not only for happiness after death, but also in this life. In addition, studies in Asian countries are more likely to produce significant correlations, because the involvement of the home environment (parents, siblings, siblings) is more religious, thus supporting children to obey religious practice, thus encouraging children to comply with the rules at school or at home including rules regarding learning.

\section{CONCLUSION}

Based on the results of the study above it can be concluded that religiosity is positively correlated with multiple intelligences with a value of $\mathrm{r} 0,41$ (strong enough/medium category). This shows that the higher the increase in the variable religiosity will have an impact on increasing multiple intelligences. In addition, problems related to the confusing power of correlation between the variables of religiosity and multiple intelligences based on varied literature (some are low to high categories) became clear after the meta-analysis was carried out, namely the moderate category. Correlations vary by type of sample.

\section{SUGGESTION}

Thus, it is recommended that the educational process of students, whether in schools, homes, or communities should help students to grow and improve religiosity that will increase various other intelligence so that they can be used in dealing with and solving various life problems.

\section{RESEARCH LIMITATIONS}

This meta-analysis only uses fewer research samples from western countries (Europe) compared to samples from Asian countries. In the context of practice, in the future it is necessary to conduct a meta-analysis related to this theme with a balanced number of samples from the west and east, or research with special samples from Europe and Asia 
specifically, so that clearer conclusions can be drawn related to the correlation of religiosity with intelligence in certain societies.

\section{REFERENCES}

Abolghasem-Gorji, H., Bathaei, S. A., Shakeri, K., Heidari, M., \& Asayesh, H. (2017). The effect of religiosity on quality of life in Muslim patients with heart failure: A study in Qom, the religious capital of Iran. Mental Health, Religion \& Culture, 20(3), 217228. https://doi.org/10.1080/13674676.2017.1329287.

Allport, G. W. (1950). The individual and his religion: A psychological interpretation. New York: Macmillian.

Alwi, Said. (2010). Pengaruh resiliensi dan religiusitas terhadap prestasi akademik remaja. (Unpublished master's thesis). Master of Science in Psychology, Gadjah Mada University, Indonesia.

Bergan, A., \& McConatha, J. T. (2001). Religiosity and life satisfaction. Activities, Adaption, \& Aging, 24(3), 23-34. DOI: 10.1300/J016v24n03_02.

Bergin, A. E. (1991). Values and religious issues in psychotheropy and mental health. American Psychologist, 46, 394-403. DOI: 10.1037/0003-066X.46.4.394.

Byfield, C. (2008). The impact of religion on the educational achievement of Black boys: A UK and USA study. British Journal of Sociology of Education, 29(2): 189-199. DOI: $10.1080 / 01425690701837547$

Cardwell, J. D. (1980). The social context of religiosity. Washington, D.C: University Press of America.

Chisiu, C. M. (2017). The religious education and the emotional intelligence. Journal Plus Education, Vol XVIII: 88-94.

Chrisnawati, A. F. I. (2008). Hubungan antara religiusitas dengan kecerdasan emosional pada mahasiswa Papua. (Unpublished undergraduate's thesis). Soegijapranata Catholic University, Indonesia.

Deify, R., \& Wahyuningsih, H. (2005). Hubungan antara inteligensi dengan religiusitas. Publication manuscrip, Indonesia IslamUniversity, Indonesia.

Dennet, D. C. (2006). Breaking the speel: religion as a natural phenomenon. London, England: Penguin Books.

Dutton, E. (2014). Religion and intelligence: an evolutionary analysis. London: Ulster Institute for Social Research.

Ebrahimi, M. R., Khoshsima, H., \& Zare-Behtash, E. (2018). The Impacts of Emotional Intelligence Enhancement on Iranian Intermediate EFL learners Writing Skill. International Journal of Instruction, 11(1), 437-452. Doi.org/10.12973/iji.2018.11130a.

Elena, A. S. (2014). Developing Emotional and Spiritual Intelligence in Children. Romanian Journal of School Psychology, 7, 13: 78-85. 
Feurestein, R., Feurestein, S., Falik, L., \& Rand, Y. (2002). Dynamic assessment of cognitive modifiability. ICELP Press: Jerusalem.

Francis, L. J. (1998). The relationship between intelligence and religiosity among 15-16 year-olds. Mental Health, Religion \& Culture, 1(2), 185-196. DOI: 10.1080/13674679808406508.

Gardner, H. (2006). Multiple intelligences new horizon. New York: Basic Books.

Gardner, H. (2011). Frames of mind the theory of multiple intelligences ${ }^{\text {third ed }}$. New York: Basic Books.

Gottfredson, L. S. (1997). Mainstream science on intelligence: An editorial with 52 signatories, history, and bibliography. Intelligence, 24, 13-23. DOI: 10.1016/s01602896(97)90011-8.

Groome, T. H. (1998). Educating for Life: a spiritual vision for every teacher and parent. Allen, TX: Thomas Moore Press.

Groome, T. H., \& Corso, M. J. (1999). Empowering catechetical leaders.Washington, DC: National Catholic Educational Association.

Hackney, C. H., \& Sanders, G. S. (2003). Religiosity and Mental Health: A MetaAnalysis of Recent Studies. Journal for the Scientific Study of Religion, 42, 1. DOI: $10.2307 / 1387984$.

Hamjah, S. H., Rozaly, E. A., Rasit, R. M., \& Ismail, Z. (2012). perkaitan amalan spiritual dengan pencapaian akademik pelajar. Asean Journal of Teaching and Learning in Higher Education (AJTLHE), 4(2), 51-60.

Hawa, M., Andayani., Suyitno., \& Wardani, N. E. (2019). The implementation of literary sociology learning model with contextual and spiritual quotient approach to teach literary sociology. International Journal of Instruction, 12(1) 283-298. https://doi.org/10.29333/iji.2019.12119a.

Jeynes, William, H. (2003). The effects of religious commitment on the academic achievement of urban and other children. Journal Education And Urban Society, 36(1), 44-62. DOI: $10.1177 / 0013124503257206$.

Jung, C. (2005). Modern man in search of a soul. New York: Taylor \& Francis eLibrary.

Lewis, G. J., Ritchie, S. J., \& Bates, T. C. (2011). The relationship between intelligence and multiple domains of religious belief: evidence from a large adult US sample. Intelligence, 39, 468-472.

Li, N., \& Murphy, W. H. (2017). Religious affiliation, religiosity, and academic performance of university students: Campus life implications for U.S university. Religion \& Education. DOI: 10.1080/15507394.2017.1398561. 
Liu, C. -C. (2010). The relationship between personal religious orientation and emotional intelligence. Social Behavior and Personality: An international journal, 38, 461-46. doi.org/10.2224/sbp.2010.38.4.461.

Marliani, R. (2016). Hubungan antara religiusitas dengan prestasi belajar pada mahasiswa fakultas syariah dan hukum uin sunan gunung djati bandung angkatan 2012. Jurnal Psikologi Integratif, 4(2), 138-147.

Mayer, J. D., Caruso, D. R., \& Salovey. P. (1999). Emotional intelligence meets traditional standards for an intelligence. Journal Intelligence, 27(4), 267-298. DOI: 10.1016/s0160-2896(99)00016-1.

Morehead, P. D. (2001). The new american roget's college thesaurus in dictionary form. New York: Penguin Putnam.

Mustafidah, L. (2008). Hubungan antara religiusitas terhadap prestasi belajar siswa muslim kelas XI sma negeri 3 Malang. (Unpublished undergraduate's thesis). Maulana Malik Ibrahim State Islamic University of Malang, Indonesia.

Nindrea, R. D. (2016). Pengantar langkah-langkah praktis studi meta analisis. Yogyakarta: Gosyen Publishing.

Ornstein, R. (2007). Multimind: a new way of looking at human behavior. Los Altos, CA: Maloor Books.

Rasmanah, M. (2003). Hubungan religiusitas dan pola asuh Islam dengan kecerdasan emosional pada remaja. (Unpublished master's thesis), Gadjah Mada University, Indonesia.

Regnerus, M. D. (2000). Shaping Schooling Success: Religious Socialization and Educational Outcomes in Urban Public Schools. Journal for the Scientific Study of Religion, 39(3), 363-370.

Retnawati, H., Apino, E., Kartianom., Djidu, H., \& Anazifa, R. D. (2018). Pengantar analisis meta. Yogyakarta: Parama Publishing.

Sari, F. (2012). Hubungan antara religiusitas dengan kecerdasan emosi pada remaja yang tinggal di pondok pesantren. (Unpublished master's thesis). University of Muhamadiyah Malang, Indonesia.

Schubmehl, J., Cubbellotti, S., \& Ornum W. V. (2009). The effect of spirituality and campus ministry on academic accomplishment in college students. Adolescence, 44, 174, 499-502.

Stark, R., \& Glock, C. Y. (1974). American piety: the nature of religious commitment. Berkeley: University of California Press.

Sternberg, R. J. (2005). The theory of successful intelligence. Interamerican Journal of Psychology, 39(2): 189-202. 
Sukmarani, M. R. (2016). Pengaruh sikap religiusitas terhadap prestasi belajar siswa kelas $v$ di sdn talangagung 02 kecamatan kepanjen kabupaten malang. (Unpublished undergraduate's thesis). University of Muhamadiyah Malang, Indonesia.

ten Kate, J., de Koster, W. \& van der Waal, J. (2017). The effect of religiosity on life satisfaction in a secularized context: Assessing the relevance of believing and belonging. Review of Religious Research, 59(135-155). https://doi.org/10.1007/s13644-016-02821.

Wahananingsih, M. (2012). Hubungan antara religiusitas, konsep diri, dan dukungan sosial keluarga dengan prestasi belajar pada siswa smp muhammadiyah 3 Depok Yogyakarta. (Unpublished master's thesis). Ahmad Dahlan University, Indonesia.

Wibowo, M.W., Susanto, D. Y., \& Sagita, N. (2015). Pengaruh sikap religiusitas terhadap prestasi belajar siswa di sma budi utomo kecamatan prambon kabupaten sidoarjo. Journal of Economics and Management, 16, 3.

Wicaksono, C. W. (2015). Hubungan religiusitas dengan prestasi akademik mahasiswa pendidikan dokter universitas muhammadiyah yogyakarta. (Unpublished undergraduate's thesis). Muhamadiyah University of Yogyakarta, Indonesia.

Widiyawati, S. (2015). Pengaruh religiusitas terhadap kecerdasan emosional remaja tuna daksa di SLB D-D1 YPAC Jakarta. (Unpublished undergraduate's thesis). Syarif Hidayatullah State Islamic University Jakarta, Indonesia.

Zikri, R. (2015). Hubungan religiusitas dengan kecerdasan moral pada kader partai keadilan sejahtera kec Tampan Pekanbaru. (Unpublished undergraduate's thesis). Sultan Syarif Kasim Riau State Islamic University, Indonesia.

Zubairu, U. M., \& Sakariyau, O. B. (2016). The relationship between religiosity and academic performance amongst accounting students. International Journal of Evaluation and Research in Education (IJERE), 5(2), 165-173. 